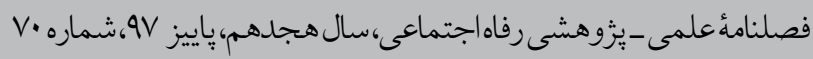

Social Welfare Quarterly, Vol 18, Fall 2018, No 70

اعتماد اجتماعى و مشاركت سياسى در شهروندان شهر

\title{
The relationship between social trust and political participation in Citizens of Gorgan
}

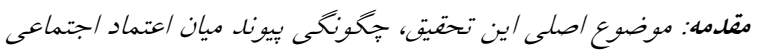

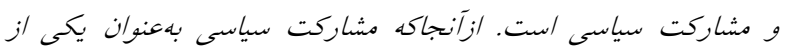

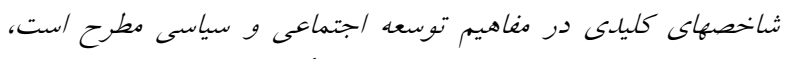

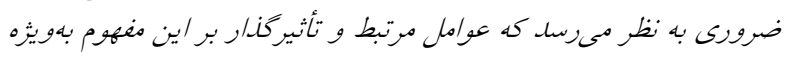

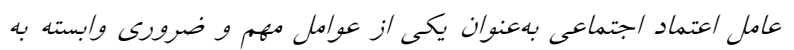

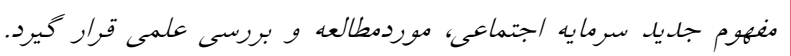

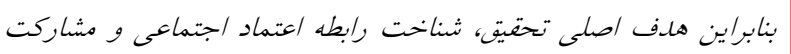
سياسى است.

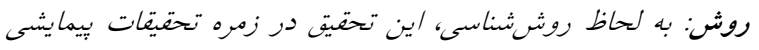

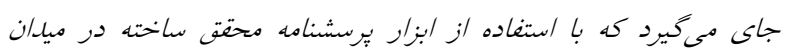

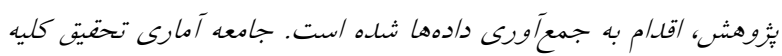

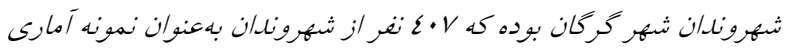

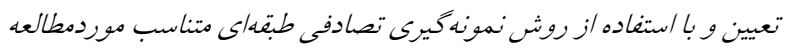

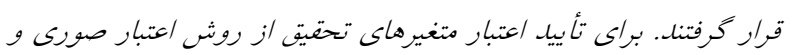

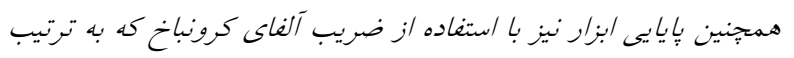

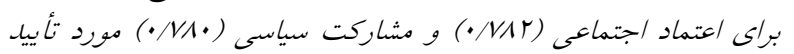

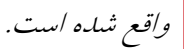

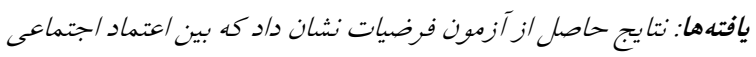

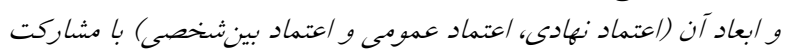

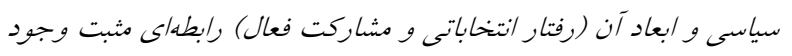

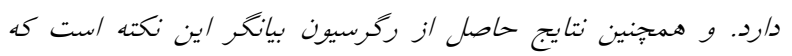

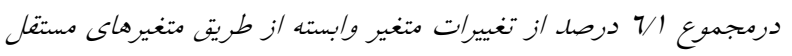
تبيين مىشود. بحث: با توجه به نتايج بهدستآمده، مادامىكه افراد به نظام حاكم،

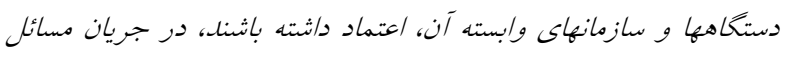

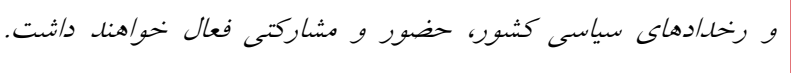

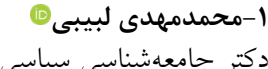

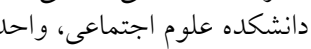
تهران مركز، دانشخاه آزاد اسلامى، واحلد، (نويسنده مسئول) (نوان مركاه <labibi_mehdi@yahoo.com>

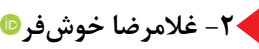
دكتر جامعهشناسى سياسى،

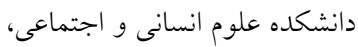

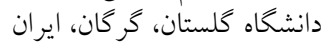

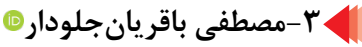

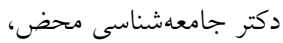
دانشكده علوم اجتماعى، دانشئاه

ييام نور سارى، سارى، ايران اجتمان دان

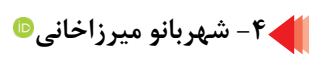

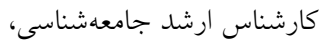

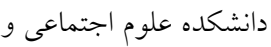

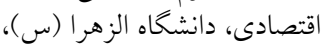
تهر ان، ايران 
Social Welfare Quarterly, Vol 18, Fall 2018, No 70

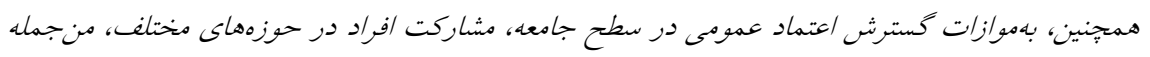

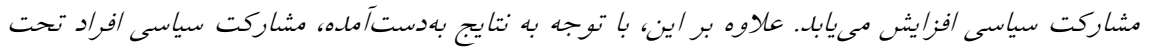

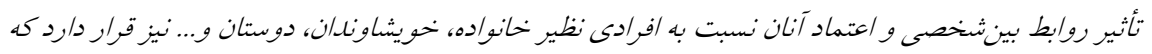

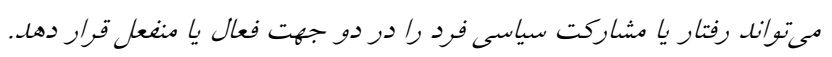

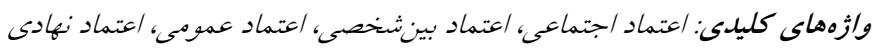

\author{
تاريخ دريافت: I/N/وا \\ تاريخ بذيرش:
}


اعتماد اجتماعى و مشاركت سياسى در شهروندان شهر كركان

The relationship between social trust and political participation ...

\section{The relationship between social trust and political participation in Citizens of Gorgan}

1- Mohammad Mehdi

Labibi 두

Ph.D in social and political sciences, Faculty of Social Sciences, Tehran Branch

Center, Islamic Azad University, Tehran, Iran, (corresponding author) $<$ labibi_mehdi@yahoo. com>

2- Gholamreza Khoshfar () $\mathrm{Ph} . \mathrm{D}$ in social and political sciences, Faculty of Humanities and Social Sciences, Golestan University, Gorgan,Iran

3- Mostafa Bagherian Jelodar (D)

Ph.D. in sociology, Faculty of Social Sciences, Payam nor University, Sari, Iran

4-Shahrbanoo Mirzakhani M.A. of Sociology, Faculty of Social Sciences, Alzahra University, Tehran, Iran
Introduction: The major goal of this study is political participation, highlighting the role of social trust. In fact, how social trust and political participation are united is analyzed and assessed. Since political participation is one of the key traits in social and political progress, influential factors need to be pointed out indeed. So the main focus of this study is to find the relationship between social trust and political participation. In addition to trust, five other basic variables have been concentrated on by the researcher. These include gender, age, education, marital status, and mental class. The theoretical framework is according to the comments of Lipst, Almond and Verba, Engleheart, Nelson and Huntington, etc. Political participation is the entry into the arena that has led to the fulfillment of a collective will or hinders its realization. Michael Rush sees political participation as being involved in various levels of an activity in the political system, from non-conflict to having a political official. The fundamental idea behind the participation is to accept the principle of equality of people, and its purpose is to promote intellectual, cooperative, and collaborative efforts to improve the quality and quantity of life in all social, economic, and political fields. In this study, in order to measure the impact of social trust on political participation, a combination of theories of social scientists and sociologists has been taken into consideration. In his book entitled Political Person, Lipst explains 


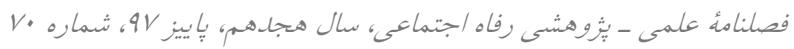

Social Welfare Quarterly, Vol 18, Fall 2018, No 70

political participation. In the book, he tries to explain the political participation of individuals,groups, and social groups based on several general social determinants, using his own sociological model. In his opinion, people participate in the following: 1. Their interests are heavily exposed to government policies, such as dependence on the government as its employee, if they are not exposed to economic constraints or have moral-religious values affected by government policies. 2. Access to information that identifies the relationship between political decisions, interests, and their interests, such as the direct and obvious effects of government policies, job training, empirical general insight, and leisure time are among the most influential factors. 3. People vote if they are exposed to social pressures; pressures, such as deprivation and alienation, the strength of the political class organization, and the level of social contact. 4. Finally, the crossover pressures, that is, individuals do not vote for the compulsion and pressure of the political parties, which have opposing interests, in different directions and in different ways, providing different information. Inglehtar also explains the increase in participation by promoting education and political information, changing the norms governing women's participation and changing value priorities. In his view, the variables of formal education, socioeconomic status, skill levels, information, communication skills, career experience, organizational networks, and the reduction of sexual differences in social and political tasks affect the increase in participation. Giddens mentions the three dynamics of modernity, the titles of the separation of time and place, from rebelliousness and appropriation. These factors have changed the model of trust in contemporary modern society; he mentions the impact of communication systems (media) on the formation of micro-level characteristics, trust in the process of socialization and personal identity, the trust of individuals in abstract and political systems, mechanisms in the current world, and the main areas of trust in a traditional world that either destroyed or neglected the traditional kinship system, local community, and religion. According to Putnam, the commonplace traditions and norms in society, including trust and cooperation are among the most important determinants of political participation. In some areas of the world where civil traditions, with trust in interpersonal relations and high public confidence, are witnessing active political participation, but political partnerships also decrease in the areas where the norms of trust and cooperation are 
اعتماد اجتماعى و مشاركت سياسى در شهرونانان شهر كركان

The relationship between social trust and political participation ...

low. Thus, trust, both among individuals and in the political trust of individuals in government, is shaped by factors, such as the rethinking process and the impact of information,the access and use of a variety of media, and other mechanisms in the modern society. Robert Putnam pointed to the fluctuations of political participation in social capital, where social trust was one of the important dimensions of Putnam's definition of social capital. Thus, Putnam's theory as one of the most appropriate theories in this field can provide a coherent framework for analyzing the relationship between social trust and political participation.

Method: This study is among those surveying research studies that use questionnaires to collect data. The subjects were the people of Gorgan, and 407 of them were chosen as a sample and the proper classes were chosen and studied using random sampling. To confirm the variable credit of the study, the formal credit method was used. Besides, the fixity of the tools was also calculated by the Cronbach's alpha coefficients, which are respectively 782 and 780 for social trust and political participation.

Findings: The findings of this study show that the average level of political participation is 825.2 out of 5 . The level of social trust of the responses was also average. The average of political participation of men was more than that of women, and that of the married was found to be more than the single. The highest political participation was between the 50 to 59 year-old people. The result of all these theories showed that there is a positive relationship among social trust and its aspects (institutional trust, public trust and people trust) together with political participation with its aspects (election behavior and active participation). The results of regression analysis show that generally $061.0 \%$ of the changes in variables is assessed via other variables, like social trust, age, sex, marital status, and education.

Discussion: According to the results, when people trust the government, institutions and organs become active participants in political incidence and happenings. As the social trust increases in the society, people participate more inpolitical events. Besides, as shown by the findings, political participation is influenced by peopl's relationship and their trust among family members, friends, and relatives, resulting in an active or inactive participantion.

Keywords: Institutional trust, Personal trust, Public trust, Social trust 


\section{مقدمه}

نظام سياسى يك كشور بر پايه اعتماد و اراده مردم شكل مى گيرد و باقى مىماند. استقرار

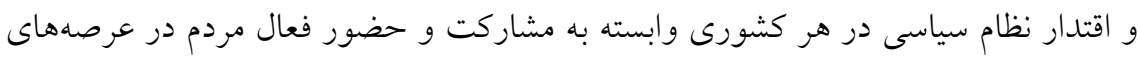
مختلف اجتماعى و سياسى است. يكى از بارزترين نمونههاى مشاركت مردمى، مشاركت دم

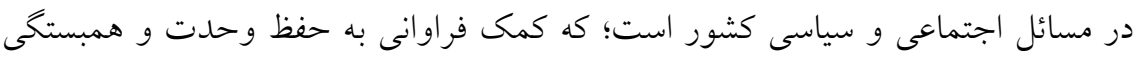
ملى مى كند. بر اين اساس مشاركت سياسى را مىتوان، فعاليت داوطلبانه اعضاى جامعه در

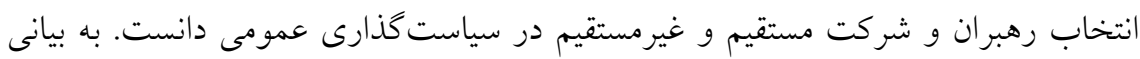

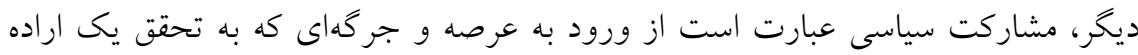

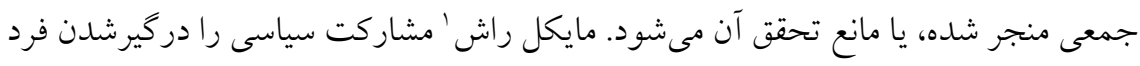

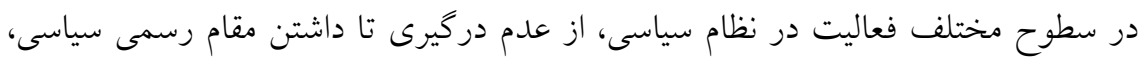

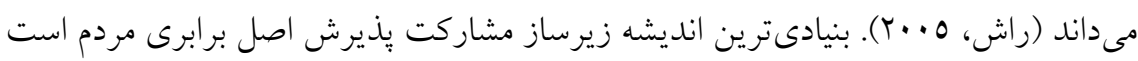
و هدف از آن، همفكرى، همكارى و تشريكمساعى افراد در جهت بهبود كميت و كيفيت

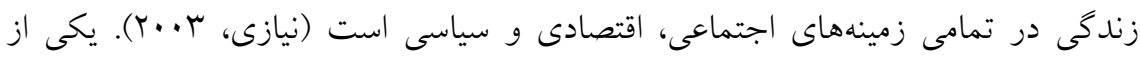
مهمترين مسائل در بحث مشاركت سياسى، مسئله اعتماد است. اعتماد يكى از جنبه هاى

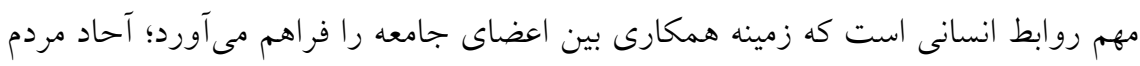
را به سوى تعاون و همكارى در گروهها و نهادهاى جامعه هدايت مى كند. تطور و تحول جوامع انسانى از حالت اوليه به مدرن در گرو يبيجيدگى، تراكم روابط اجتماعى و و ارتباط

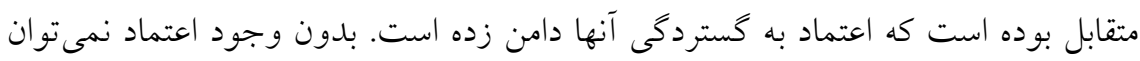

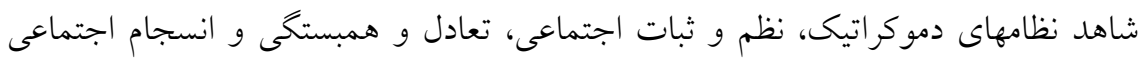

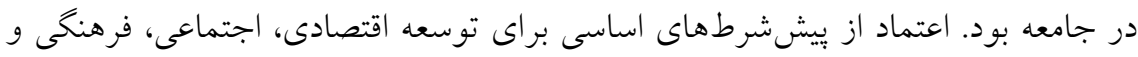
سياسى هر جامعهاى محسوب مىشود. همجنين اعتماد مىتو اند عاملى در جهت تعامل فرد برد

1. Michael Rush 
The relationship between social trust and political participation ...

يا افراد جامعه با دولت باشد. براين اساس، حضور مردم در مشاركت و همكارى مسائل مربوط به جامعه، به ميزان اعتماد متقابل بين آنها، دولت و نهادهاى وابسته به آن بستخى دارد. بالينوجود بررسيها نشانخر آن است كه نوعى بحران در اساسىترين شاخص سرمايه اجتماعى يعنى اعتماد اجتماعى به وجود آمده است كه مستلزم بررسى دقيقتر و علمى است. ازنظر آنتونى كيدنز'، جوامع مدرن به نظامهاى تخصصى اعتماد تكيه مى كنند و اين بدان معناست كه اعتماد كليد رابطه بين فرد و نظامهاى تخصصى است. در بررسيهاى اكتشافى بهعمل آمده مشاهده مىشود كه اعتماد اجتماعى در بسيارى از جوامع از وضعيت مطلوبى برخوردار نيست. ازنظر انديشمندان و صاحبنظران ايرانى نيز شواهد بسيارى دلالت بر كاهش اعتماد اجتماعى در ايران، در تمام سطوح وجود دارد و بهطريق اولى كاهش سطح اعتماد، بر تغيير سطح مشاركت سياسى تأثير گذار بوده است. علاوه بر عامل مهم اعتماد، عوامل ديخرى نيز بر مشاركت سياسى تأثير كذارند كه در اين يزوهش موردنظر نبودهاند. در مورد انتخاب قلمرو مكانى يُزوهش قابلتأمل است كه شهر كركان مركز استان كلستان است و ازنظر بسيارى، نخين اقوام ايرانى خوانده شده و كروههاى قومى و مذهبى متنوعى در آن زندگى مى كنند. تنوع قومى و مذهبى موجب ايجاد شكافهاى اجتماعى فراوانى مىشود كه مشاركت سياسى را تحت تأثير خود قرار مىدهند. نتايج برخى از مطالعات انجام شده در استان كلستان نشان مىدهد كه ميزان مشاركت مردم در انتخابات مجلس شوراى اسلامى از دوره ششم به دوره هفتم به مقدار IT/TV

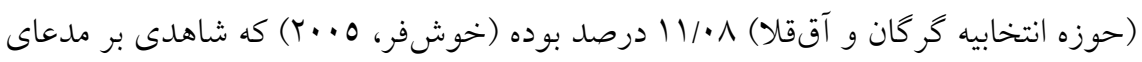
كاهش مشاركت سياسى در شهر كر گان است. بنابراين با توجه به اين موضوع، مسئله اصلى يزووهش حاضر مشاركت سياسى است كه با تأكيد بر نقش اعتماد اجتماعى موردمطالعه قرار

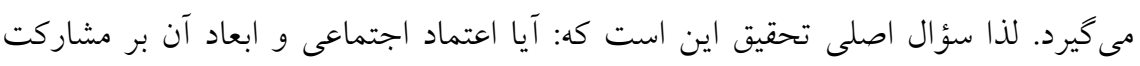
1.Anthony Giddens 
سياسى تأثير گذارند؟ و در صورت تأييد، كميت و كيفيت اين تأثير گذارى جگگ نه است؟

\section{ييشينه تجربى}

مشاركت به معنى بهكار كرفتن منابع شخصى به منظور سهيمشدن در يك اقدام جمعى است (محسنى و جاراللهى، ع. ·ץ). كرفت و بيراسفورد' تحولاتى جون ظهور جنبشهاى اجتماعى جديد، تأمل و بازنكرى در مورد نياز انسان، ظهور مجدد ايده شهروندى و يُستمدرن را موجب توجه به ايده مشاركت دانستهاند (نيازى، س..r). متخصصان علوم اجتماعى بهويزه دانشمندان جامعهشناسى و علماى علوم سياسى براى تبيين و تشخيص ميزان مشاركت سياسى و عوامل مؤثر بر آن، نظريات متفاوتى مطرح كردهاند كه در اين قسمت به

$$
\text { توضيح برخى از آنها يرداخته مىشود. }
$$

نلسون وهانتينگتون 'مشاركت سياسى را بهعنو ان امرى عينى و جدا از نخرشهاى ذهنى فرد در نظر مى گيرند. به اعتقاد آنها مشاركت سياسى عبارت است از فعاليت شهروندان خصوصى به منظور تأثير نهادن بر فرآيند تصميم گيريهاى دولت. نخرش كلى نلسون وهانتينكتون اين است كه فرآيند توسعه اقتصادى و اجتماعى از طريق دو مجرا مىتواند سرانجام به گسترش مشاركت سياسى و اجتماعى بيانجامد:

راه اول، تحرك اجتماعى: به اين معنى كه كسب منزلتهاى اجتماعى بالاتر بهنوبه خود در فرد احساس توانايى در تأثيرنهادن بر تصميم گيريهاى دستخاههاى عمومى را ايجاد مى كند و اين عوامل ذهنى مىتواند مشوق مشاركت در سياست و فعاليت اجتماعى باشد. در اين حالت، منزلت اجتماعى بالاتر و احساس مؤثربودن ازنظر سياسى، بهعنوان متغيرهاى ميانى، مشوق مشاركت اجتماعى و سياسى محسوب مىشود. به نظر اين دو نويسنده، از ميان متغيرهاى منزلتى، ميزان سواد و تحصيلات فرد بيشترين تأثير را بر مشاركت سياسى دارد. 
The relationship between social trust and political participation ...

راه دوم، شيوه سازمانى: يعنى عضويت و مشاركت فعال در انواع گروهها و سازمانهاى اجتماعى (اتحاديههاى شغلى و صنفى، كروههاى مدافع علايق خاص و...) است كه احتمال مشاركت در فعاليت اجتماعى و سياسى را بيشتر مى كند. اين عامل در جوامعى كه فرصت تحرى فردى در آنها محدودتر است، اهميت بيشترى دارد. زيرا همانطور كه كفته شد، به اعتقاد اين نويسند گان، فرد براى رسيدن به وضع اجتماعى و اقتصادى بهتر، بهعنوان آخرين

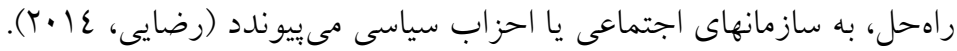
اينخلهارت' فرض مى كند كه اعتماد به يكديخر بخشى از نشانخان فرهنخى بايدار است كه به بقاى دموكراسى منجر مى شود. وى در كتاب تحول فرهنكى در جامعه بيشرفته صنعتى تلاش مى كند تا به اين سؤال اساسى يّاسخ دهد كه آيا تفاوتهاى فرهنخى در اعتماد به يكديخر وجود دارد؟ او معتقد است كه درصورتىكه اين موضوع حقيقت نداشته باشد، هرگونه بحث درباره تأثير سياسى بلندمدت آن بىاثر است. شواهد و يافتهاى او نشان مىدهند كه سطح اعتماد در جوامع مختلف با هم تفاوت دارد. او همجنين معتقد است كه سطوح عالى اعتماد به يكديخر با دموكراسى با ثبات نيز رابطه دارد. به نظر او سطوح نسبتاً يايين انتشار رضايت و اعتماد موجب مىشود كه شخص بهاحتمالزياد نظام سياسى مو جود را نيذيرد و از راست يا جֶٍ افراطى حمايت كند. بهزعم او رضايت از زندگى، رضايت سياسى، اعتماد به يكديخر، ميزان زياد بحث سياسى و حمايت از نظم اجتماعى موجود، همه همراه هم هستند. آنها نشانگحان نخرشهاى مثبت را نسبت به جهانى كه شخص در آن زندكى مى كند، تشكيل مىدهند. جالبتر از همه اين واقعيت است كه اين نشانگان با بقاى نهادهاى دموكراتيك رابطه دارد. او در تفسير اين رابطه اظهار مىدارد كشورهايى با سطوح بالاى رضايت از زندكى و اعتماد متقابل بسيار بيشتر احتمال دارد كه نهادهاى دموكراتيك را يذيرفته، آن را حفظ كنند تا آن گروه از كشورهايى كه افراد آن فاقد جنين نخرشهايى هستند. برعكس،

1. Inglehart 
نهادهاى دموكراتيك به احتمال بيشتر در كشورهايى با سطوح يايين رضايت از زندكى و

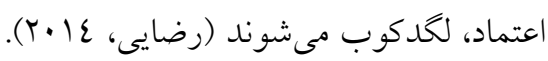
يوررنجبر و همكاران (سوسا) در مطالعهاى تحت عنوان بررسى تأثير اعتماد اجتماعى لـى بر شيوهاى مختلف مشاركت سياسى در ميان دانشجويان دانشخاه اصفهان برداختهاند. استنباط آمارى از دادهها نشاندهنده تأثير اعتماد اجتماعى بر بنج سطح مشاركت سياسى مئى (حمايت كنند گان منفعل، تماس با مسئولان سياسى، ارتباطات سياسى، مبارزان سياسى و اعتراض كنندكان سياسى) است. البته يافتههاى بزّوهش نشان داد كه اعتماد اجتماعى بر

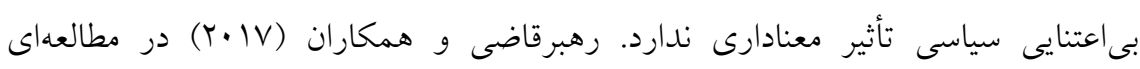
تحت عنوان بررسى سرمايه اجتماعى بر مشاركت در انتخابات به بررسى تأثير ابعاد اعتماد اجتماعى، هنجارهاى اجتماعى مشوق همكارى و شبكه اجتماعى بهمثابه عناصر سازنده سرمايه اجتماعى بر ميزان مشاركت افراد در انتخابات در بين دانشجويان دانشخاههاى دولتى شهر اصفهان يرداختهاند. نتايج حاصل از تحليل فرضيههاى اصلى حاكى از آن بود كه از يك تيك تئي طرف اعتماد اجتماعى و هنجارهاى اجتماعى بر تقويت شبكههاى اجتماعى تأثير مى گذارد و از سوى ديخر، اعتماد اجتماعى و شبكههاى اجتماعى نيز بر افزايش ميزان مشاركت در انتخابات تأثير مثبت و معنىدارى دارد. همجينين يافتههاى يزّوهش نشان داد كه رابطه معنى دارى ميان هنجارهاى اجتماعى و مشاركت در انتخابات وجود ندارد. شكربيكى و يناهى (rا • (Y) مطالعهاى تحت عنوان عوامل اجتماعى مؤثر در مشاركت سياسى اجتماعى زنان (موردمطالعه: زنان شهر گنبدكاووس در استان كلستان) انجام دادهاند. بر اساس تحليل رگرسيونى دادهاى تحقيق، از ميان جهار متغير مستقل، متغير اعتماد اجتماعى مهمترين تبيين كننده مشاركت سياسى اجتماعى زنان بوده است و متغيرهاى سن، پيايخاه اجتماعى دئى اقتصادى و وضعيت تأهل به ترتيب بهعنوان تبيين كنندهاى بعدى متغير وابسته هستند. 
The relationship between social trust and political participation ...

امامجمعهزاده و همكاران (T/ (Y) به بررسى سرمايه اجتماعى و مشاركت سياسى در ميان دانشجويان دانشخاه اصفهان يرداختهاند. با توجه به نتايج تحقيق بهدستآملده، فرضيه تحقيق مبنى بر همبستخى معنادار ميان ابعاد سرمايه اجتماعى و اعتماد بهعنوان يكى از ابعاد مهم آن

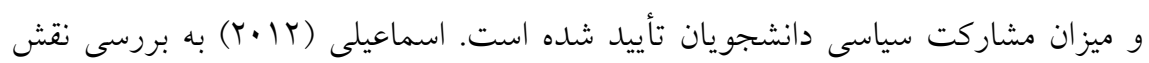
عوامل اجتماعى بر مشاركت سياسى در شهرستان كنبد برداخته است. نتايج نشانكر آن است كه بين سن، پايخاه شغلى، وضعيت اقتصادى، سطح تحصيلات، ميزان استفاده از رسانهها، ميزان ارتباط با مراكز شهرى بزرى و ميزان اعتماد به دولت با ميزان مشاركت سياسى آنان رابطه مثبت و معنادارى وجود دارد. در باب رابطه بين اعتماد اجتماعى و مشاركت سياسى دو ديدكاه مطرح مىشود. در ديدگاه نخست، بر وجود ارتباط ضعيف بين اعتماد اجتماعى و مشاركت سياسى تأكيد مىشود. براين اساس يزوهشهاى موجود درزمينه سرمايه اجتماعى نشان مىدهند كه اخرجه

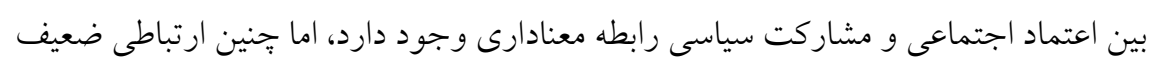
است (رايت، 19V7). كاس' (1999) در تحقيق خود نتيجه گيرى مى كند كه رابطه آمارى بين

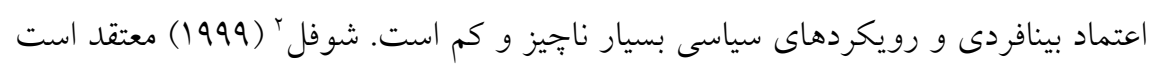

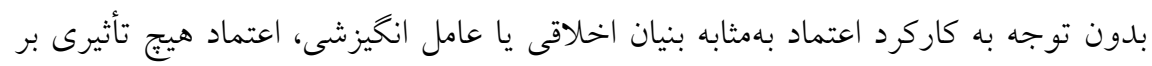

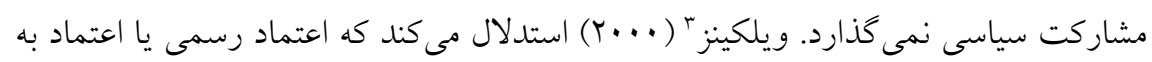
نظام سياسى هيج ارتباطى با مشاركت سياسى يا حتى بى اعتنايى به آن ندارد. در ديد گاه دوم، نتايج تحقيقات نشان مىدهند كه بين اعتماد اجتماعى و مشاركت سياسى رابطهاى قوى وجود دارد. در حقيقت اين نتايج نشان مىدهد كه همسو با نظريههاى سرمايه

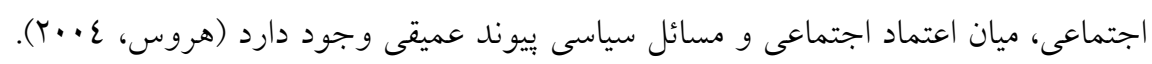

1. Cass

2. Shvfl

3. Wilkins 
جنين اعتمادى مىتواند انخيزه فعاليتهاى داوطلبانه را به وجود آورد و استانداردهاى اخلاقى لازم را براى هدايت افراد فراهم كند. اوسلانر' (ع . .ب) استدلال مى كند در جوامعى كه اعتماد زيادى بين افراد وجود دارد، فساد سياسى كمتر و فرهنگ همكارى و مشاركت سياسى بيشترى در آنجا به وجود مى آيد. در محيط كروهى، افر ادى كه داراى اعتماد اجتماعى بيشترى هستند بر مفهوم عمل متقابل تكيه مى كنند. اعضاى جنين خروههايى معمولاً احساس مي كنتد كه از طريق توسعه اعتماد اجتماعى و مشاركت، در جنين گروههايى مىتوانند بِاداشهاى اجتماعى بيشترى به دست آورند. فوكوياما' (1990) بر اهميت اعتماد و هنجارهاى عمل متقابل در جهت موفقيت كروه بيشتر از قوانين و مقررات رسمى تأكيد مى كند. فوكوياما معتقد است جوامع و انجمنهاى موفق نه براساس قوانين و مقررات رسمى و مكتوب، بلكه براساس آداب و تعهدات اخلاقى درونىشده اعضاى هر جامعه و در نتيجه اعتماد اجتماعى تشكيل مىشوند. لين "معتقد است جو امعى كه در آن بيوندهاى اجتماعى نسبتاً قوى وجود دارد باعث ايجاد اعتماد تعميميافته مىشوند و جنين اعتمادى مانع انزواطلبى و فروياشى همكاريهاى

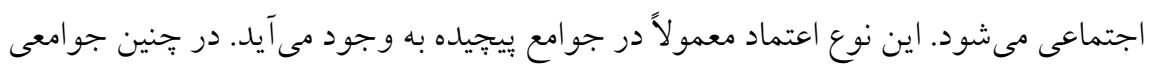
افراد به قوانينى تكيه مى كنند كه بسيارى از شهروندان آنها را يذيرفتهاند و نمادها و مبادلات بينافردى را هدايت مىكند. بدون وجود اعتماد اجتماعى و جنين قوانين يذيرفتهشدهاى كاركردهاى اجتماعى، ممكن است متوقف شوند (1 (Y. ب). بنابراين اعتماد اجتماعى احتمالاً باعث مىشود ميزان مشاركت افراد در فعاليتهاى سياسى، رأىدهى ستادهاى تبليغاتى، فعاليت درزمينهها و مسائل محلى، منطقهاى و... به دليل كسترش قوانين يذيرفته شده افزايش يابد (اوسلانر، 1999، به نقل از مسعودنيا و همكاران، 10 • (Y).

1. Uslanr

2. Fukuyama

3. Lin 
The relationship between social trust and political participation ...

״ياتنام' در توضيح اعتماد متقابل بهمنزله سنگبناى سرمايه اجتماعى آن را مفصل و رابط

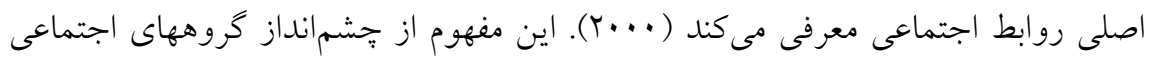
بيشتر فهميدنى است. اعضاى كروههاى اجتماعى بهطور منظم با هم در تماس هستند. بدين ترتيب مشكلات و مسائل مختلف از طريق بحثهاى منظم آشكار مىشوند. شهروندانى كه در جنين انجمنهايى مشاركت مى كنند با افراد مختلفى ملاقات مى كنند. اين امر خنانجه در محيط سالم و مثبتى صورت گيرد باعث تقويت ويز گيهاى مثبت در افراد و باعث ايجاد اعتماد در آنها مىشود. هنگامى كه بيخانحان به جنين گروههايى وارد مىشوند اعضاى گروه آنها را به شكلى مثبت درك مى كنند و بدين ترتيب در جارجهوب جنين گروههايى به افراد ناشناس نيز اعتماد مىشود. يّاتنام استدلال مى كند كه انجمنهاى اجتماعى و اعتماد اجتماعى ناشى

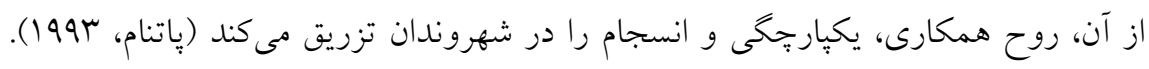
اعتماد اجتماعى به افراد كمك مى كند تا روح همكارى در ميان آنها از طريق رفتارهاى مشترك توسعه يابد. اعتماد تعميميافته باعث مىشود كه افراد بلدون هيج گونه جششمداشتى به دنبال كمك ديخران باشند. جنين افرادى از طريق شركت در كارويزههاى اجتماعى به شهروندان بهترى تبديل مىشوند. آنها معمولاً بيش از ديخران به كارهاى خيريه مىيردازند، به تعهدات مالياتى خود عمل مى كنند، به ديدگاه اقليتها احترام مى گذارند و در ديخر اشكال همكاريهاى مدنى شركت مى جويند. اين افراد نهتنها تعهدات مدنى خود را به شكلى بهتر انجام مى دهند، بلكه در فرآيند مشاركت سياسى نيز فعاليت بيشترى مى كنند (ياتنام، .... با، به نقل از مسعودنيا و همكاران، 0 (ب) (ب).

\section{جارجوب نظرى}

جارجوب نظرى يكى الكوى مفهومى است مبتنى بر روابط تئوريك ميان شمارى از

1. Putnam 
عواملى كه در مورد مسئله مورديزوهش با اهميت تشخيص داده مىشوند. اين نظريات با

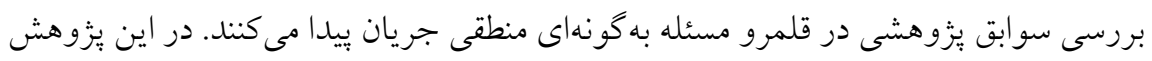

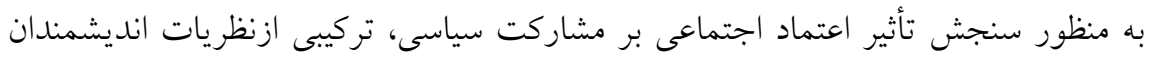

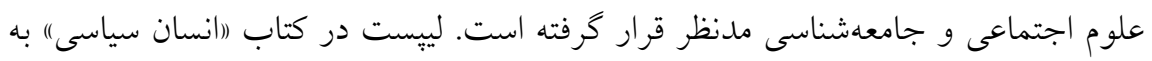

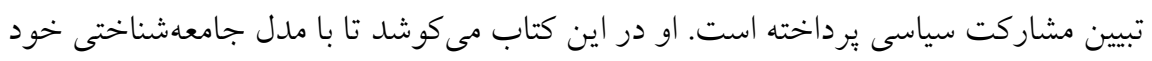

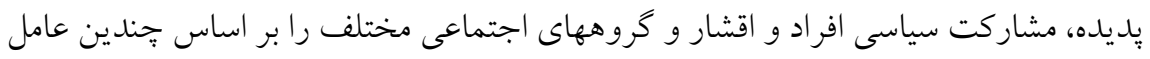

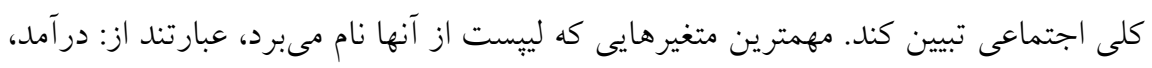

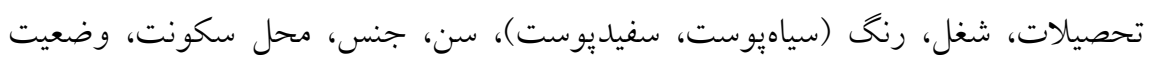
تأهل، وضعيت و سامان جامعه. در كنار متغيرهاى فوق، يكى سرى عوامل اجتماعى نيز بر نرخ مشاركت سياسى تأثير جدى مى گذارند. به نظر او افراد در صورتى مشاركت مى كنند كه:

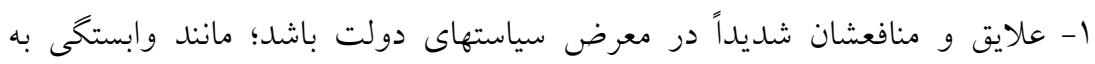

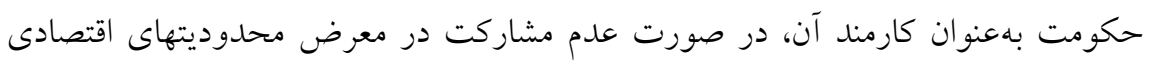

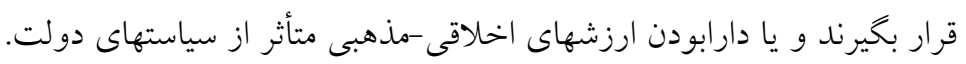

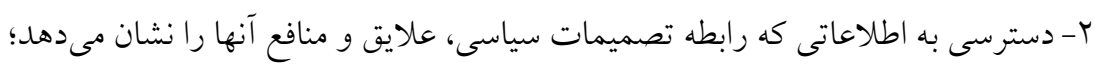

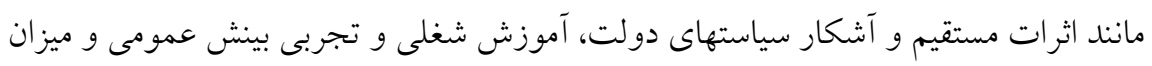
اوقات فراغت ازجمله عوامل تأثير كذار معرفى شدهاند.

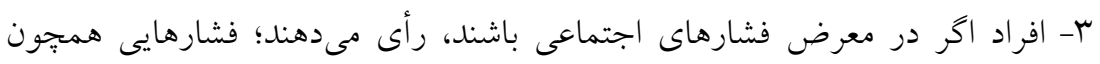

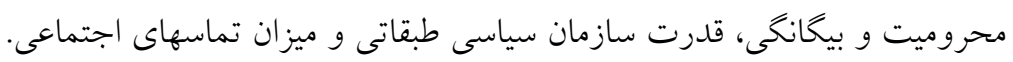

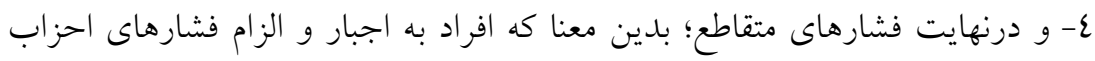
سياسى كه هريك منافع متضادى نسبت به هم دارند، از جهات و به شيوههاى مختلف اقدام 
The relationship between social trust and political participation ...

مى كنند و اطلاعات مختلف و متفاوتى را ارائه مىدهند، رأى ندهند. در آخر ليِيست نتيجه مى گيرد كه مشاركت صرفنظر از جهت اهداف آن، براى تحقق برخى مقاصد توسعه سياسى و اجتماعى ضرورى است؛ اكر جهه ممكن است جهت و مقصد اين مشاركت در هر كشور با ديخر كشورها متفاوت باشد. اينخلهارت نيز افزايش مشاركت را از طريق ارتقاى سطح تحصيلات و اطلاعات سياسى؛ تغيير هنجارهاى حاكم بر مشاركت زنان و تغيير در اولويتهاى ارزشى، مورد تبيين قرار داده است. به نظر او متغيرهاى تحصيلات رسمى، موقعيت اجتماعى -اقتصادى، سطوح مهارت و اطلاعات، مهارتهاى ارتباطى، تجربههاى شغلى، شبكههاى سازمانى، تقليل تفاوتهاى جنسى در وظايف اجتماعى و سياسى، بر افزايش مشاركت تأثير مى كذارند. در نهايت كيدنز از سه سرجشمه بويايى مدرنيته ياد مى كند؛ تحت عناوين جدايى زمان و مكان، از جاكندگى و تخصيص بازانديشانه. اين عوامل، الكوى اعتماد را در جامعه مدرن امروزى تغيير دادهاند؛ او از تأثير نظامهاى ارتباطاتى (رسانهها) بر شكل گيرى ويزگيهاى سطح خرد، از اعتماد در فرآيند اجتماعىشدن و هويت شخصى تا اعتماد فرد به نظامهاى انتزاعى و سياسى ياد مى كند كه مكانيسمهاى موجود در جهان كنونى زمينههاى اصلى اعتماد در جهان سنتى كه از نظام خويشاوندى سنتى، اجتماع محلى و ديندارى را يا از بين برده و يا كماهميت كرده است. بدين ترتيب اعتماد، جهه در بين افراد و جهه بهصورت اعتماد سياسى افراد به حكومت، تحت تأثير عواملى جون روند بازانديشانه و تأثير اطلاعات و دسترسى و استفاده از انواع رسانهها و مكانيسمهاى ديخر در جامعه مدرن شكل مى گيرند. رابرت بِاتنام نيز انديشمند سياسى مبرزى بود كه حدود ro سال در مناطق شمالى و جنوبى كشور ايتاليا به تحقيق يزوهش درباره نوسانات مشاركت سياسى برحسب سرمايه اجتماعى ترداخت كه اعتماد اجتماعى يكى از ابعاد مهم تعريف ياتنام از سرمايه اجتماعى بود. طبق نظر پاتنام (1999) ستتها و هنجارهاى رايج در جامعه از جمله اعتماد و همكارى از مهمترين عوامل متمايزكننده 
Social Welfare Quarterly, Vol 18, Fall 2018, No 70

مشاركت سياسى هستند. بلهورى كه در مناطقى از جهان كه سنتهاى مدنى همراه با اعتماد

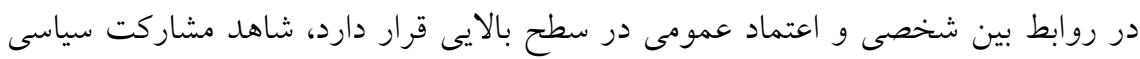

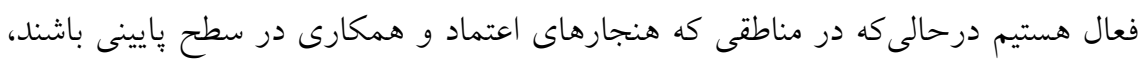

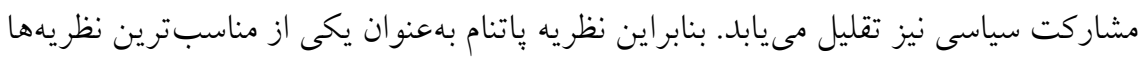

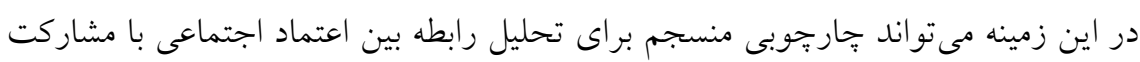

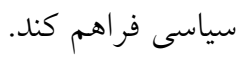

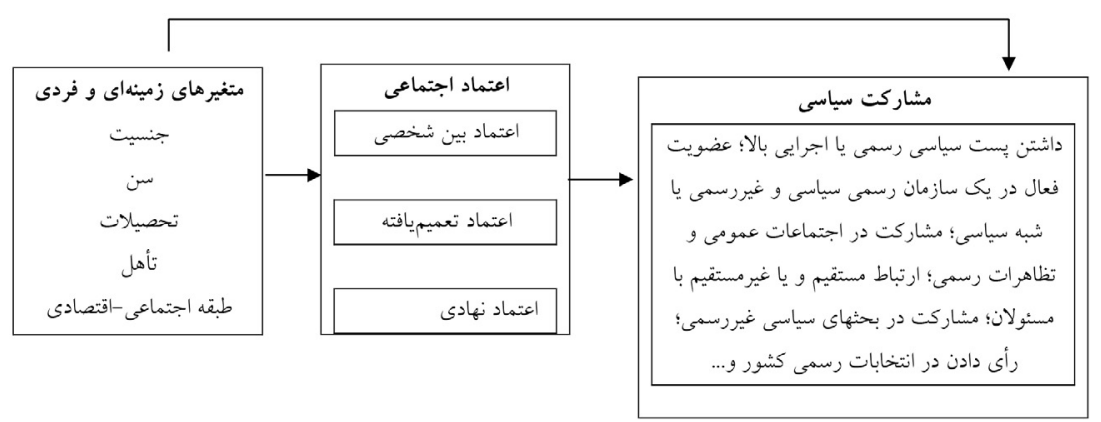

شكل (1) مدل نظرى تحقيق 


\section{روش}

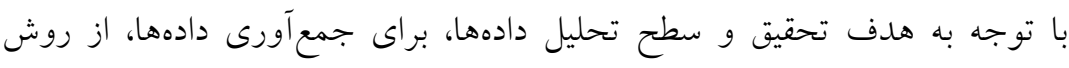

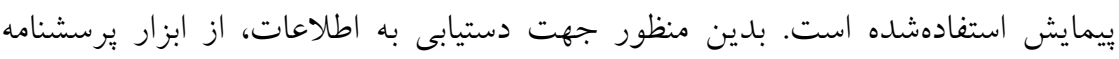

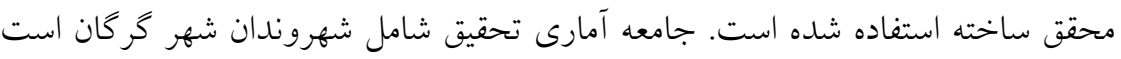

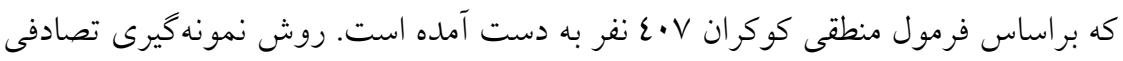

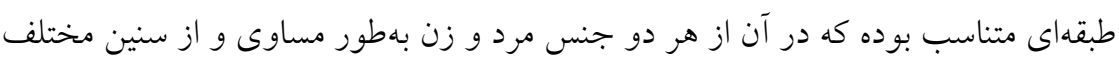

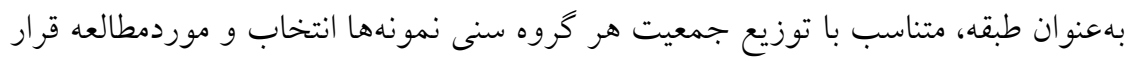

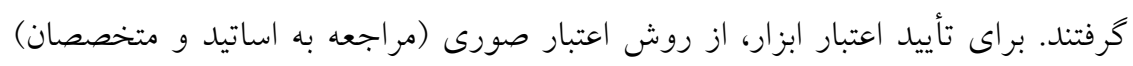

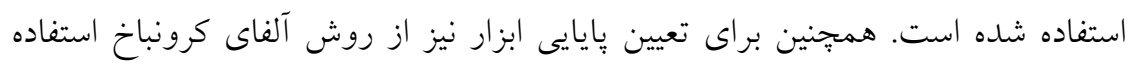

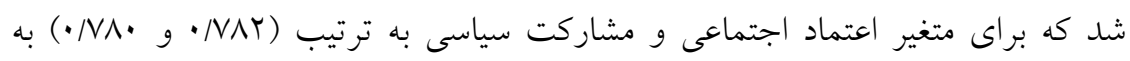

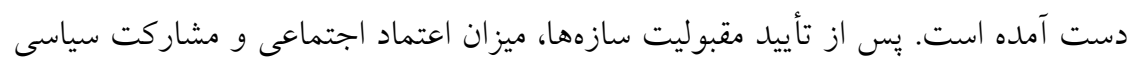

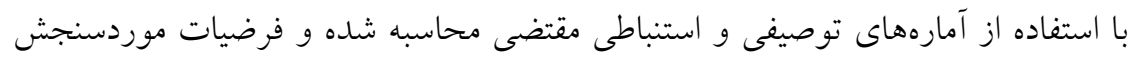
قرار مى گيرند.

تعريف نظرى مشاركت سياسى: هر نوع فعاليت سياسى داوطلبانه در رابطه با احراز،

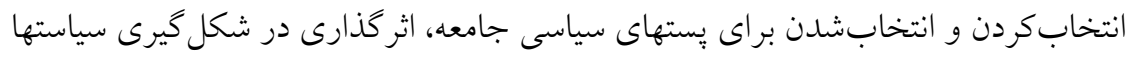

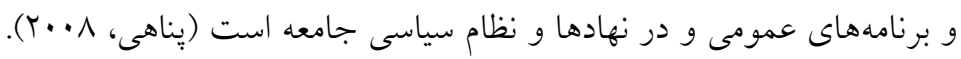

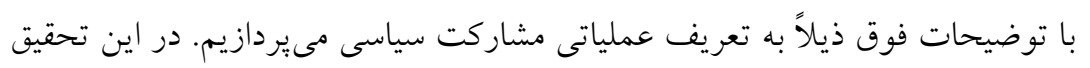

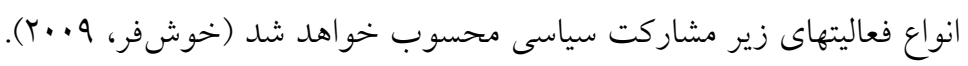

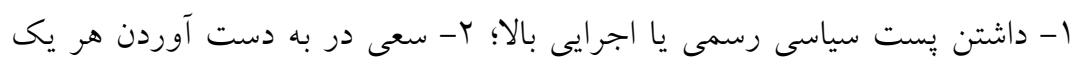

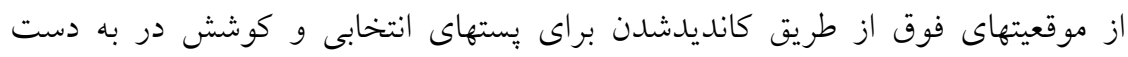

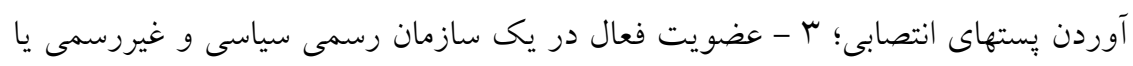


شبه سياسى، شامل احزاب سياسى، ائتلافها، گروهها، محفلها و انجمنهاى سياسى رسمى و غيررسمى كه معمولاً در انتخابات مختلف كشور كانديد معرفى مى كنند؛ ع- مشاركت در اجتماعات عمومى و تظاهرات رسمى موردحمايت نظام و اجتماعات و تظاهرات غيررسمى و حمايت نشده از جانب نظام سياسى؛ 0- عضويت انفعالى در يك سازمان رسمى سياسى و يا يك سازمان شبه سياسى؛ 7- ارتباط مستقيم (شفاهى يا كتبى) و يا غيرمستقيم (از طريق

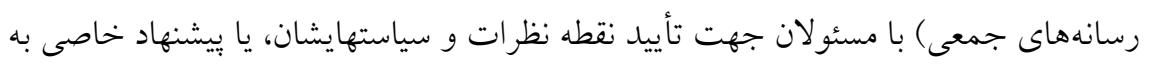
آنان و يا تذكر در جهت اصلاح نظارت و سياستهاى آنان؛ V- مشاركت در بحثهاى سياسى غيررسمى؛ ^- اندكى علاقه به سياست عبارت است از اظهار علاقه به مسائل سياسى و بحث

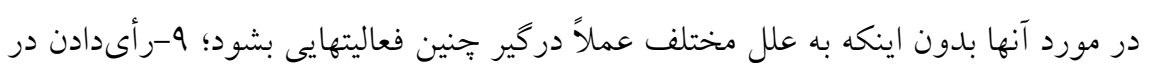

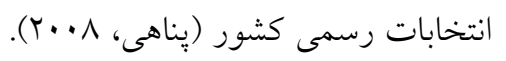

تعريف نظرى اعتماد اجتماعى: ياتنام (1999) در تعريف اعتماد بيان مىدارد كه (شما براى انجام كارى صرفاً به دليل اينكه فردى (نهادى) مى گويد آن را انجام خواهد داد به او اعتماد نمى كنيد. بلكه شما تنها به اين دليل به او اعتماد مى كنيد كه با توجه به شناختتان از خلقوخوى او، انتخابهاى ممكن او، تبعاتشان و توانايى او حدس مىزنيد كه او انجام اين كار را برخواهد گزيد). در ادبيات سرمايه اجتماعى، جهار نوع اعتماد قابلتشخيص است: ا- اعتماد به نزديكان يا اعتماد بينشخصى: اين نوع اعتماد از طريق برسشهايى در خصوص اعتماد به اعضاى خانواده و نزديكان موردسنجش قرار مى كيرد. ץ- اعتماد تعميميافته: سنجش اين نوع اعتماد بهواسطه كار پاتنام (1990) انجام كرفته است. او با استفاده از دادههاى بيمايش ارزشهاى جهانى يك گويه منفرد را مورد تحليل قرار داد (كريشنا و شرايدر، 1999). اين گويه به شرح زير است: 
The relationship between social trust and political participation ...

$$
\begin{aligned}
& \text { در كل با اين عبارات موافقيد: } \\
& \text { - به اغلب مردم مى توان اعتماد كرد؟ } \\
& \text { - اكثر مردم صادقند؟ - }
\end{aligned}
$$

ب- قابليت اعتماد عموم (اعتماد به غريبهها): اخر كيف يول خود را كه در آن يول نيز

هست گم كنيد، فكر مى كنيد يكى از همسايخان به شما كمك مى كند تا آن را بيدا كنيد؟ اكر كيف يول خود را كه در آن بول نيز هست در همسايخى خود گم كنيد، فكر مى كنيد

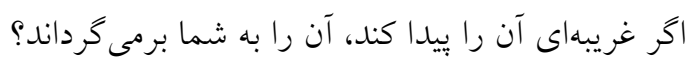

اكر كسى اتومبيلش در نزديكى منزل شما خر اب شود، آيا شما او را براى استفاده از تلفن

$$
\text { منزلتان دعوت مى كنيد؟ (اونيكس و بولن، .... (Y). }
$$

ع- اعتماد نهادى: يكى از معمولترين روشهاى سنجش اعتماد مدنى يا نهادى، ارائه فهرستى لـى

از نهادها و سازمانهاى رسمى و يرسش از يُسخحويان در مورد ميزان اعتماد به آنها است.

\section{يافته ها}

در اين قسمت، ابتدا به نتايج توصيفى فراوانى سطوح و ميانخين مشاركت سياسى و ابعاد آن يرداخته شده است. براين اساس همانطور كه ملاحظه مىشود، ميزان مشاركت

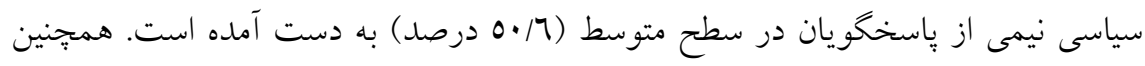
ميانگين مشاركت سياسى نيز س// از م كزارش شده است كه نشاندهنده حد متوسطى از مشاركت سياسى پِاسخگ يان است. اما در باب ابعاد مشاركت سياسى نيز، بيش از نيمى از ״ياسخگويان (09/0 درصد) در سطح بايينى از مشاركت فعال سياسى قرار گرفتهاند؛ و در بعد رفتار انتخاباتى نيز بيشترين فراوانيها به ترتيب متعلق به سطوح متوسط (0/9ع درصد) و بالا (• • (برصد) است. درمجموع با توجه مقادير ميانخين محاسبهشده، ميانخين رفتار انتخاباتى ياسخخويان بيشتر از مشاركت فعال و مشاركت سياسى به دست آمده است. 


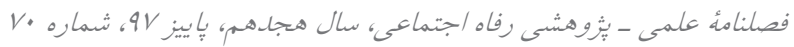

Social Welfare Quarterly, Vol 18, Fall 2018, No 70

جدول (1) توزيع فراوانى، سطوح و ميانخين نمرات مشاركت سياسى باسخگويان

\begin{tabular}{|c|c|c|c|c|c|c|c|}
\hline \multirow{2}{*}{ SD } & \multirow{2}{*}{$\mathbf{M}$} & \multicolumn{5}{|c|}{ سطوح مشاركت سياسى (تعداد و درصد) } & \multirow{2}{*}{ متغير } \\
\hline & & خيلى بالا & بالا & متوسط & بايين & خيلى يايين & \\
\hline$\cdot /$ UV & T/ATO & $\varepsilon(1 / \cdot)$ & $7 \varepsilon(10 / V)$ & $r \cdot \tau(0 . / 7)$ & $1 T r(r \cdot / r)$ & $1 \cdot(T / 0)$ & مشاركت سياسى \\
\hline $1 / 7 \vee \varepsilon$ & T/YTA & $1 \varepsilon(\Gamma / \varepsilon)$ & $r \cdot(\varepsilon / q)$ & $V I(I V / \varepsilon)$ & TEY $(09 / 0)$ & $7 \cdot(\mid \varepsilon / V)$ & مشاركت فعال \\
\hline $1 / \varepsilon V \mu$ & $r / 197$ & $T \varepsilon(0 / 9)$ & $\operatorname{lr}(r \cdot / \cdot)$ & $\operatorname{l\wedge V}(\varepsilon 0 / 9)$ & $\Delta \wedge(\mid \varepsilon / \Gamma)$ & $17(1 / 9)$ & رفتار انتخاباتى \\
\hline
\end{tabular}

در جدول شماره (Y)، به بررسى ويزگ گيهاى ياسخگگيان برحسب متغيرهاى مستقل و زمينهاى نظير جنس، سن، تحصيلات، وضعيت تأهل و طبقه اجتماعى -اقتصادى، با لحاظكردن سطح و ميانگين مشاركت سياسى يرداخته شده است. در قسمت جانبى جدول نيز متغير مفهومى و وابسته يزوهش يعنى اعتماد اجتماعى نيز برحسب مشاركت سياسى موردبررسى قرار گرفته است. با توجه به جدول، تعداد مردان و زنان اختلاف بسيار كمى نسبت به هم دارند. اما با مشاهده سطوح مشاركت مردان در هر ينج سطح مطروحه، مىتوان نتيجه گيرى كرد كه ميزان مشاركت سياسى مردان بيش از زنان است. عدد ميانخين به دست آمده نيز كوياى اين مطلب است؛ ميانخين مشاركت سياسى مردان (Y/AY) و زنان (Y/VY)

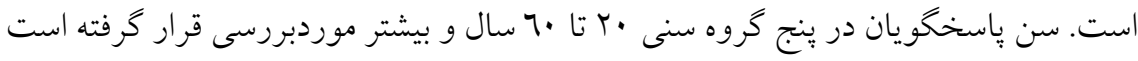

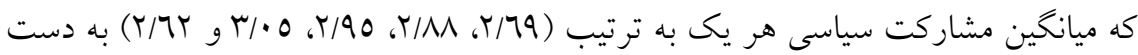

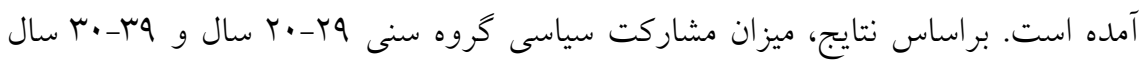
بيشتر از سه گروه ديخر به دست آمده است؛ اما بالاترين مقدار ميانخين مشاركت سياسى در

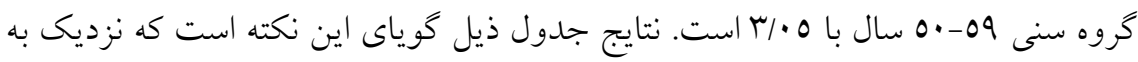
نيمى از پاسخخويان (7/9 درصد) داراى مدرى تحصيلى زيرديبلم، و بالاتر و IV/T درصد دييلم هستند. در اين ميان ياسخگويانى كه مدرك تحصيلى خود را زيردييلم اعلام كردهاند، در ينج سطح مشاركت سياسى، نسبت به دو كروه ديخر بيشترين 
The relationship between social trust and political participation ...

ميزان مشاركت سياسى را داشته است. ميانخين مشاركت سياسى برحسب تحصيلات در ميان ياسخخويان با مدرى تحصيلى كاردانى و بالاتر (Y/A9) بيشتر به دست آمده است. الV درصد از جمعيت نمونه متأهل و بو درصد مجرد هستند. ميانخين مشاركت سياسى باسخخويان

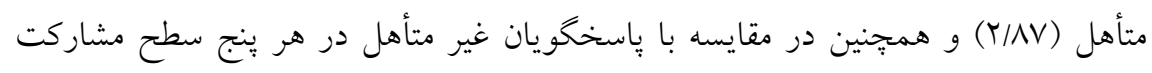
سياسى نيز، بيشترين ميزان را به دست آوردهاند. متغير طبقه اجتماعى -اقتصادى (طبقه ذهنى)

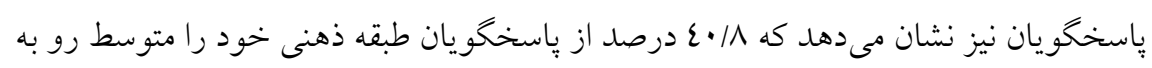

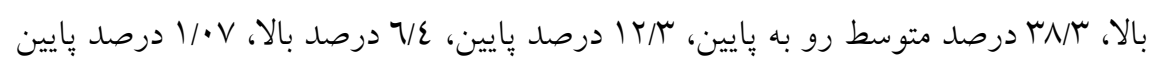
يايين و 10 • درصد بالاى بالا عنوان كردهاند. ميزان مشاركت سياسى طبقات مذكور در سطح متوسط مشاركت سياسى بيش از جهار سطح ديخر گزارش داده شده است. همدنين ميانخين مشاركت سياسى باسخخويانى كه طبقه ذهنى خود را بالا ذكر كردهاند با (T/Y/M) بيش از ساير طبقات به دست آمده است. اما در قسمت انتهايى جدول اعتماد اجتماعى پِاسخكويان در بنج

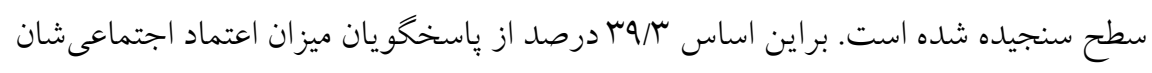
در حد متوسط و Mو درصد بالا به دست آمده است. اما سطح مشاركت سياسى باسخخويان برحسب ميزان اعتماد اجتماعى نيز نشان مىدهد كه بيشترين ميزان مشاركت سياسى در ميان ياسخخويانى بوده كه اعتماد اجتماعيشان در حد متوسط كزارش شده است؛ و در نهايت ميانخين مشاركت سياسى برحسب اعتماد در كروهى كه اعتماد اجتماعى بالايى دارند، بيشتر از ساير خروهها است. 
جدول (Y) توزيع فراوانى بِاسخكويان، سطوح و ميانگين نمرات مشاركت سياسى متغيرهاى موردمطالعه

\begin{tabular}{|c|c|c|c|c|c|c|c|c|c|}
\hline \multirow{3}{*}{$\begin{array}{c}\text { SD } \\
\text { / } 7 \mathrm{Vq} \\
\end{array}$} & \multirow{3}{*}{$\begin{array}{c}\mathbf{M} \\
\text { Y/QYY } \\
\end{array}$} & \multicolumn{5}{|c|}{ سطوح مشاركت سياسى (درصد) } & \multirow{3}{*}{ تعداد (درصد) } & \multirow{2}{*}{\multicolumn{2}{|c|}{ مشخصات فردى }} \\
\hline & & \multirow{2}{*}{ بالا } & \multirow{2}{*}{ بالا } & \multirow{2}{*}{ متوسط } & \multirow{2}{*}{ "ايين } & \multirow{2}{*}{ خيلى هايين } & & & \\
\hline & & & & & & & & مرد & \multirow{2}{*}{ جنس } \\
\hline$\cdot / \mathrm{AV} \mid$ & T/VYV & $r / \cdot$ & $\mathrm{M} / \mathrm{A}$ & $1 \cdot r / T$ & $71 / \cdot$ & .10 & $(\Sigma q / 7) r \cdot r$ & زن & \\
\hline.$/ 791$ & $r / 790$ & $1 / 0$ & $r \mu / \mu$ & V乏/9 & $\varepsilon \varepsilon / V$ & $r / 7$ & $(\Gamma-/ \varepsilon) \backslash \varepsilon \wedge$ & $r \cdot-r q$ & \multirow{5}{*}{ 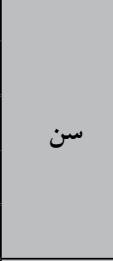 } \\
\hline$\cdot / 9 \Lambda Y$ & Y/AMI & $\cdot / 9$ & $1 \varepsilon / 7$ & $\varepsilon \mathrm{V} / \mathrm{1}$ & YN/1 & $r / \Gamma$ & $(Y Y / Q) q T$ & $r \cdot-r q$ & \\
\hline$\cdot / \mathrm{AN}$ & $r / 90 \varepsilon$ & $\cdot / 7$ & $1 \cdot / 2$ & $\mu r / \varepsilon$ & $19 / 9$ & $1 / 7$ & $(17 / T) 77$ & $\varepsilon \cdot-\varepsilon q$ & \\
\hline - $/$ V 10 & $r / .0$. & $\cdot / 7$ & $9 / 2$ & $r \cdot / \varepsilon$ & $1 / N \mid$ & $1 / 0$ & $(\mid \varepsilon / N) 7$. & $0 .-09$ & \\
\hline$\cdot / 170$ & r/7TO & $\cdot / \varepsilon$ & $T / \mu$ & $r \cdot / r$ & $\mid r / 1$ & $1 / \cdot$ & $(9 / \Lambda) \varepsilon \cdot$ & ل ال سال و بيشتر & \\
\hline $1 / \Gamma \varepsilon \wedge$ & T/VVE & $1 / 9$ & $r \cdot / 7$ & $97 / \mathrm{V}$ & $\mathrm{OV} / \cdot$ & $\varepsilon / \Lambda$ & $(27 / 9) 191$ & زير دييلم & \multirow{3}{*}{ تحصيلات } \\
\hline$\cdot / 717$ & r/AOV & $\cdot / \mathrm{V}$ & $11 / r$ & $r 0 / \varepsilon$ & $r \cdot / 9$ & $1 / 1$ & $(I V / Y) V \cdot$ & ديبم & \\
\hline$\cdot / 901$ & $r / \wedge 9 \Lambda$ & $1 / \varepsilon$ & $r r / l$ & $79 / 9$ & $\varepsilon 1 / \Gamma$ & $r / 0$ & $(\Pi \pi / 9) \mid \mu_{\Lambda}$ & كاردانى و بالاتر & \\
\hline$\cdot / 7 \mathrm{rV}$ & Y/AVY & $1 / r$ & $1 / / 7$ & $09 / \mathrm{V}$ & ro/v & $r / 9$ & $(r 9 / \cdot) 111$ & مجرد & \multirow{2}{*}{ وضأهل } \\
\hline $1 / \varepsilon \vee \wedge$ & T/VII & $r / \Lambda$ & $0 \varepsilon / \varepsilon$ & $1 \varepsilon 7 / r$ & $\Lambda V / r$ & $V / 1$ & $(V / / \cdot) Y \wedge q$ & 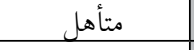 & \\
\hline I/TAV & r/OVI &.$/ 1$ & $1 / 1$ & $r / 0$ & $r / 1$ & $\cdot / r$ & $(1 / \mathrm{V}) \mathrm{V}$ & بايين يايين & \multirow{6}{*}{ 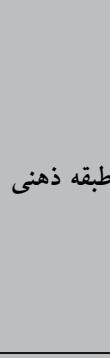 } \\
\hline$\cdot / 9 \wedge \varepsilon$ & $r / \Lambda$. & .10 & $V / 9$ & ro/r & $10 / 1$ & $1 / r$ & $(1 T / \Gamma) 0$. & ليايين & \\
\hline$\cdot / 701$ & T/VTY & $1 / 0$ & $r \varepsilon / 0$ & $\mathrm{vq} / \cdot$ & $\varepsilon V / 1$ & $r / \Lambda$ & $\left(\Gamma^{N} / \Gamma^{\mu}\right) 107$ & متوسط رو به & \\
\hline.$/ 41$ & Y/A19 & $1 / 7$ & $r \bar{r} /$ & $\wedge \varepsilon / \cdot$ & $0 . / \pi$ & $\varepsilon / 1$ & $(\varepsilon \cdot / \wedge) 177$ & متوسط رو به بالا & \\
\hline$\cdot / 941$ & $r / r 79$ & $\cdot / \mu$ & $\varepsilon / 1$ & $1 \% / r$ & $V / 9$ & $\cdot / 7$ & $(\eta / \varepsilon) Y\urcorner$ & بالا & \\
\hline$\cdot / v \wedge \varepsilon$ & $r / \cdots$ & . & $\cdot \pi$ & $1 / \cdot$ & $\cdot / 7$ & . & $(\cdot / 0) Y$ & بالاى بالا & \\
\hline$\cdot / \mathrm{W} A$ & $r / V \cdot \cdot$ & $\cdot / \Lambda$ & $r / 9$ & $r / 9$ & $1 / \Lambda$ & $\cdot 10$ & $r \cdot(\varepsilon / 9)$ & خيلى يايين & \multirow{5}{*}{ اجتماعى اعتماد } \\
\hline I/ TAV & $r / 9\{7$ & $1 \cdot / \mu$ & ro/v & $\varepsilon \Lambda / \varepsilon$ & $r T / V$ & $\mathrm{y} \cdot$ & Vo $(\mid \wedge / \varepsilon)$ & بِياين & \\
\hline$\cdot / 901$ & r/V07 & $I V / T$ & $09 / \mathrm{V}$ & $\Lambda \mathrm{I} / \cdot$ & $\mathrm{r}_{\mathrm{\Lambda} / \cdot} \cdot$ & $1 \cdot / 1$ & $17 \cdot(r 9 / \Gamma)$ & متوسط & \\
\hline.$/ 741$ & Y/AEV & $0 / \mu$ & $1 / / 7$ & ro/r & $11 / \mathrm{A}$ & $r / 1$ & $1111(\mathrm{Tq} / \cdot)$ & بالا & \\
\hline$\cdot / 9 \wedge \mathrm{V}$ & T/AMY & $\cdot \pi$ & $1 / r$ & $1 / 7$ & $\cdot / \mathrm{V}$ & $\cdot / r$ & $r q(\Lambda / \varepsilon)$ & خيلى بالا & \\
\hline
\end{tabular}


The relationship between social trust and political participation ...

در اين قسمت تحليل دادهها با استفاده از تكنيكهاى آمارى متناسب با سطح سنجش متغيرها انجام كرفته است. نتايج جدول (r) رابطه اعتماد اجتماعى و مشاركت سياسى را در سطح كلى و برحسب ابعاد هر دو متغير نمايش مىدهد. براى آزمون رابطه ميان متغير مستقل و وابسته تحقيق از آزمون ضريب همبستخى بيرسون استفاده شده است. همانطور كه ملاحظه مىشود، سطح معنادارى اعتماد اجتماعى با ضريب اطمينان 99 درصد و سطح خطاى ا درصد، (VI\&/•) به دست آمله است. اين امر بدان معناست كه ميزان اعتماد اجتماعى افر اد تأثير مثبت و مستقيم بر ميزان مشاركت سياسى آنان دارد. البته با توجه به مقدار سطح معنادارى مىتوان اين رابطه را در سطح ضعيف قضاوت نمود. اما جنانجه مشاهده مىشود، بين اعتماد اجتماعى و رفتار انتخاباتى نيز رابطه معنادارى در با ضريب اطمينان 99 درصد و سطح معنادارى (r • • •) وجود دارد؛ البته شدت اين رابطه در مقايسه با مشاركت سياسى ضعيفتر است. بدين ترتيب فرض تحقيق مبنى بر رابطه و تأثير كذارى متغير اعتماد

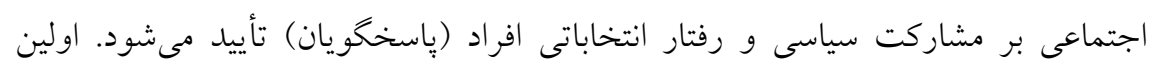
بعد اعتماد اجتماعى، بعد اعتماد عمومى است. اعتمادى كه در سطح جامعه افراد نسبت به يكديخر و نسبت به نهادها دارند. در اين زمينه شاهد رابطه مثبت و قوىاى بين اعتماد عمومى با مشاركت سياسى با ضريب اطمينان 90 درصد و سطح معنادارى (0 • • •) و مشاركت فعال با سطح معنادارى (9 • • •) هستيم. با توجه به اين مقادير مىتوان نتيجه كيرى نمود كه ميزان مشاركت سياسى افراد و مشاركت فعالشان در امور و جريانات سياسى منوط به شعاع و كستردگى اعتماد عمومى در سطح جامعه و افراد آن است. در بعد اعتماد بين شخصى نيز شاهد رابطه معنادار مشاركت سياسى و رفتار انتخاباتى پِاسخگويان هستيم. بر اين اساس

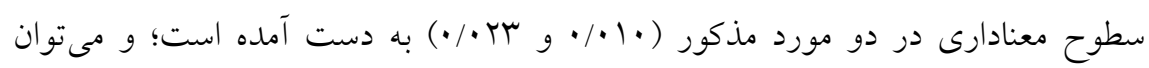
نتيجه كيرى كرد كه سطح اعتماد بينشخصى افراد در رفتار و ميزان مشاركت سياسى ايشان و حضور يا عدم حضور در انتخابات تأثير گذار است. در نهايت، همجنان كه ملاحظه مىشود، 
هيج گونه رابطه معنادارى ميان اعتماد نهادى با مشاركت سياسى و ابعاد آن به دست نيامده است؛ اين امر بدان معناست كه سطح اعتماد و يا بى اعتمادى افراد به نهادها و سازمانهاى جامعه بر رفتار و ميزان مشاركتشان در امور سياسى تأثير گذار نيست. جدول (r) آزمون ضريب همبستخى بين اعتماد و مشاركت سياسى

\begin{tabular}{|c|c|c|c|}
\hline$p$ & $\mathbf{r}$ & متغير وابسته & متغيرهاى مستقل \\
\hline$\cdot / \cdot \varepsilon V^{*}$ & .1 .99 & مشاركت سياسى & \multirow{3}{*}{ اعتماد اجتماعى } \\
\hline$\cdot / \cdot \Lambda r^{*}$ & $\cdot / \cdot 17$ & رفتار انتخاباتى & \\
\hline.$/ 190$ & $\cdot / \cdot 7 \varepsilon$ & مشاركت فعال & \\
\hline$\cdot 1 \cdots 0^{m *}$ &.$/ 1 \varepsilon$. & مشاركت سياسى & \multirow{3}{*}{ اعتماد عمومى } \\
\hline$\cdot / \cdot \mathrm{VV}$ & $\cdot / \cdot \Lambda \Lambda$ & رفتار انتخاباتى & \\
\hline$\cdot / \cdots 9^{* * *}$ & $\cdot / \mu$ & مشاركت فعال & \\
\hline • r &.$/ .0$. & مشاركت سياسى & \multirow{3}{*}{ اعتماد نهادى } \\
\hline . & $\cdot / \cdot \varepsilon \wedge$ & رفتار انتخاباتى & \\
\hline.$/ 077$ & $.1 \cdot r q$ & مشاركت فعال & \\
\hline.$/ \cdot 1 \cdot *$ &.$/ I T V$ & مشاركت سياسى & \multirow{3}{*}{ اعتماد بين شخصى } \\
\hline$\cdot 1 \cdot r r^{*}$ &.$/ 111$ & رفتار انتخاباتى & \\
\hline $.11 \ldots$ & $\cdot / \cdot \Lambda r$ & مشاركت فعال & \\
\hline
\end{tabular}

$* p<\bullet / \bullet \quad * * p<\cdot / \cdot 1$

براى سنجش و ارزيابى رابطه بين متغيرهاى جنسيت و وضعيت تأهل از آزمون t با دو نمونه مستقل استفاده شده است. براساس آزمون تفاوت ميانخينها و معنادارى ارائهشده در جدول، مىتوان كفت مشاركت سياسى افراد و ابعاد آن (رفتار انتخاباتى و مشاركت فعال) بر اساس جنسيت متفاوت است. براين اساس فرض تحقيق $\left(H_{1}\right)$ تأييد مىشود كه مبنى بر تفاوت ميزان مشاركت سياسى مردان و زنان است. مقايسه ميانخين دو گروه نيز تفاوت ميزان 
The relationship between social trust and political participation ...

مشاركت سياسى مردان و زنان را نشان مىدهد؛ كه نشانخر بالابودن ميزان مشاركت سياسى مردان نسبت به زنان است. در ادامه همانطور كه نتايج نشان مىدهند، بين مشاركت سياسى و مشاركت فعال باسخگويان با وضعيت تأهل ايشان تفاوت معنادارى وجود ندارد؛ و تنها بين رفتار انتخاباتى پِاسخحويان با وضعيت تأهلشان تفاوت معنادارى به دست آمده است. بهطورىكه براساس ميانگين دو گروه مجرد و متأهل، مىتوان نتيجه گيرى كرد كه متأهلها بيشتر از غير متأهلها در انتخابات شركت مى كنند.

جدول (ع) آزمون تفاوت ميانغين متغيرهاى جنسيت و وضعيت تأهل با مشاركت سياسى و ابعاد آن

\begin{tabular}{|c|c|c|c|c|c|c|c|c|}
\hline$P$ & $\mathrm{t}$ & آزمون لون & SD & M & $\mathrm{n}$ & طبقات & متغير وابسته & متغير مستقل \\
\hline \multirow{2}{*}{$\cdot / \cdots 1$} & \multirow{2}{*}{ ז/אר } & \multirow{2}{*}{$\cdot / 9 \varepsilon r$} & $1 / \cdot 1$ & $r / 70$ & $r \cdot 0$ & مرد & \multirow{2}{*}{ سشاركت } & \multirow{6}{*}{ جنسيت } \\
\hline & & & $1 / 1$. & $r /$. & $r \cdot r$ & زن & & \\
\hline \multirow{2}{*}{$\cdot 1 \cdot \cdot 1$} & \multirow{2}{*}{$r / r l$} & \multirow{2}{*}{$\cdot / \cdot \varepsilon \varepsilon$} & $\cdot / 9$ & $r / 9 Y$ & $r \cdot 0$ & مرد & \multirow{2}{*}{ انتخاباتى رفتار } & \\
\hline & & &.$/ 97$ & $r / r l$ & $T \cdot T$ & زن & & \\
\hline \multirow{2}{*}{.$/ 19$} & \multirow{2}{*}{$T / T \varepsilon$} & \multirow{2}{*}{$\cdot / 111$} & $1 / N 1$ & $r / \mu \Lambda$ & $r .0$ & مرد & \multirow{2}{*}{ مشاركت } & \\
\hline & & & $1 / \Lambda$. & $r / V q$ & $r \cdot r$ & زن & & \\
\hline \multirow{2}{*}{$\cdot / V \wedge 9$} & \multirow{2}{*}{$\cdot / r u$} & \multirow{2}{*}{.1090} & $1 / 11$ & T/OV & 111 & مجرد & \multirow{2}{*}{ سياسى } & \multirow{6}{*}{ وضعيت تأهل } \\
\hline & & & $1 / 70$ & $r / 7 r$ & rAq & متأهل & & \\
\hline \multirow{2}{*}{$\cdot / \cdot \cdot 1$} & \multirow{2}{*}{$-r / \mu V$} & \multirow{2}{*}{$\cdot / \cdot \vee \wedge$} & $\cdot / 19$ & Y/AY & 111 & مجرد & \multirow{2}{*}{ انتخاباتى رفتار } & \\
\hline & & & $1 / \cdot T$ & $r / I V$ & rAq & متأهل & & \\
\hline \multirow{2}{*}{$\cdot / V \wedge 9$} & \multirow{2}{*}{$\cdot / r T$} & \multirow{2}{*}{.1090} & $1 / \cdot V$ & r/AV & 111 & مجرد & \multirow{2}{*}{ فشاركت } & \\
\hline & & & $1 / \cdot 7$ & YNT & rAq & متأهل & & \\
\hline
\end{tabular}


براى آزمون رابطه بين متغيرهاى سن و تحصيلات با متغير وابسته و ابعاد آن از آزمون

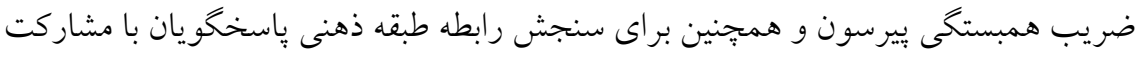

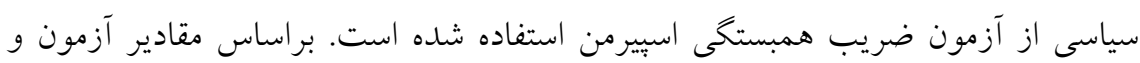

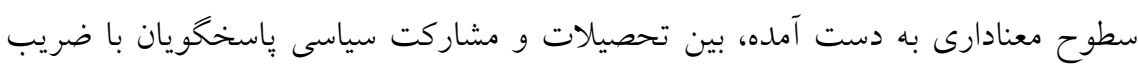

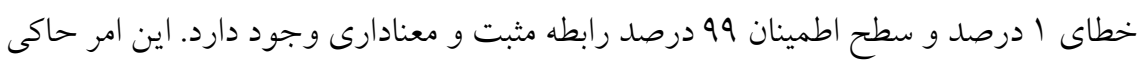

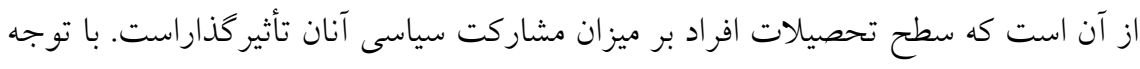

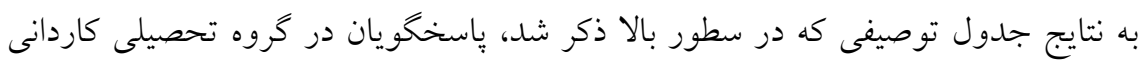

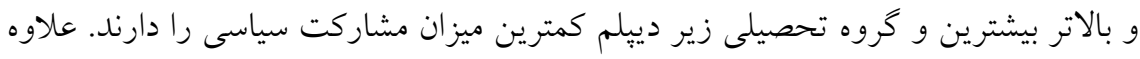

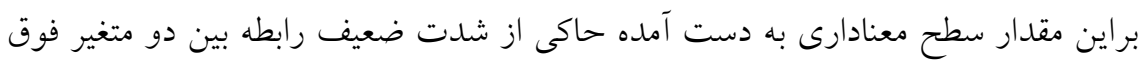
است. در مورد متغيرهاى رفتار انتخاباتى و مشاركت فعال، فرض رابطه معنادار با متغير سن لن

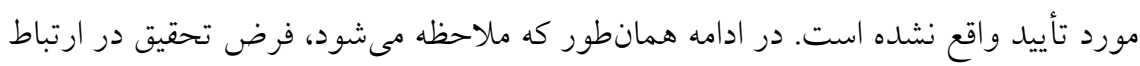

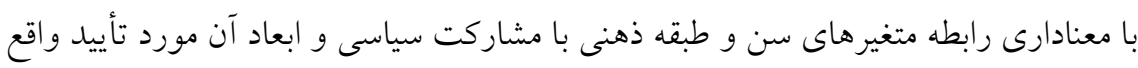

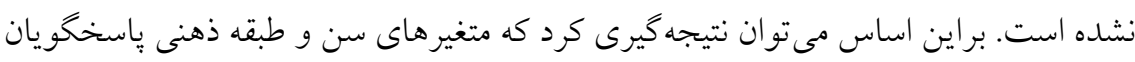

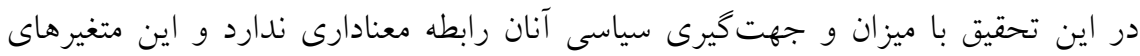
مستقل بر متغير وابسته (مشاركت سياسى) و ابعاد آن تأثير كذار نيستند. 
اعتماد اجتماعى و مشاركت سياسى در شهرونالدان شهركركان

The relationship between social trust and political participation ...

جدول (0) آزمون ضريب همبستخى بين متغيرهاى زمينهاى و مشاركت سياسى و ابعاد آن

\begin{tabular}{|c|c|c|c|}
\hline$p$ & $\mathbf{r}$ & متغير وابسته & متغيرهاى مستقل \\
\hline .1 .9$. & $\cdot / \cdot \wedge \varepsilon$ & مشاركت سياسى & \multirow{3}{*}{ سن سن } \\
\hline$\cdot / r \cdot 7$ &.$/ .01$ & رفتار انتخاباتى & \\
\hline$\cdot / 1 \cdot \varepsilon$ & $\cdot / \cdot 11$ & مشاركت فعال & \\
\hline • &.$/ 11 \mathrm{r}$ & مشاركت سياسى & \multirow{3}{*}{ تحصيلات } \\
\hline .1 .90 & 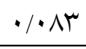 & رفتار انتخاباتى & \\
\hline.$/ .7 V$ & .1 .91 & مشاركت فعال & \\
\hline$p$ & $\mathbf{r}_{\mathrm{s}}$ & متغير وابسته & متغيرهاى مستقل \\
\hline . / TO &.$/ .0 \mathrm{~V}$ & مشاركت سياسى & \multirow{3}{*}{ طبقه ذهنى } \\
\hline$\cdot / \varepsilon \varepsilon$ &.$/ .4 \Lambda$ & رفتار انتخاباتى & \\
\hline .1 .90 & $\cdot / \cdot \Lambda \mu$ & مشاركت فعال & \\
\hline
\end{tabular}

در انتها براى مشخص كردن تأثير و معنادارى رابطه هر يك از متغيرهاى مستقل بر متغير

وابسته از روش رگرسيون جند گانه استفاده شد كه نتايج آن به شرح ذيل است:

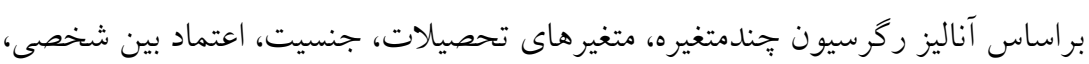

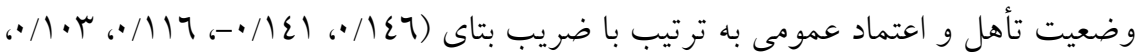

97 × • • با ميزان مشاركت سياسى شهروندان رابطه معنادارى داشتند. همجنان كه ملاحظه

مىشود ضريب همبستكى بين متغيرهاى مستقل و مشاركت سياسى برابر با الج / • است.

درواقع متغيرهاى مستقل مىتوانند ال درصد از واريانس مشاركت سياسى را بهصورت تعديلشده تبيين مى كنند. 


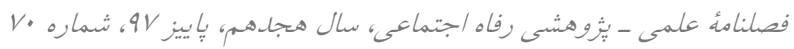

Social Welfare Quarterly, Vol 18, Fall 2018, No 70

جدول (7) نتايج رگرسيون جند آنه مدل تأثير متغيرهاى مستقل بر مشاركت سياسى شهروندان

\begin{tabular}{|c|c|c|c|c|c|}
\hline$p$ & $\mathbf{t}$ & $\boldsymbol{\beta}$ & $\mathbf{R}^{r}$ & $\mathbf{R}$ & متغير هاى مستقل \\
\hline$\cdot / \cdots \varepsilon$ & $-Y / \Lambda T Y$ & $-\bullet / \mid \sum \backslash$ & \multirow{7}{*}{$\cdot / \cdot 71$} & \multirow{7}{*}{$\cdot / T V \Lambda$} & جنسيت \\
\hline$\cdot / \cdot v 7$ & I/VVA & $\cdot / 1 \cdot r$ & & & تأهل \\
\hline • TYY & $1 / r \mid \Lambda$ & $\cdot / \cdot \mathrm{VI}$ & & & سن \\
\hline.$\cdots 0$ & 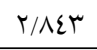 & $\cdot / 1\{7$ & & & تحصيلات \\
\hline.$/ . \mu T$ & T/1OY &.$/ 117$ & & & اعتماد بين شخصى \\
\hline$\cdot / \cdot 71$ & I/AMY &.$/ .97$ & & & اعتماد عمو مى \\
\hline$\cdot / \mu \cdot V$ & $-1 / \cdot r \varepsilon$ & -.1 .00 & & & اعتماد نهادى \\
\hline
\end{tabular}

بحث

در بررسى رابطه ميان دو متغير اصلى تحقيق، اعتماد اجتماعى و مشاركت سياسى نتايج حاصل از تجزيهو تحليل دادهها به ارتباط معنى دار و مستقيم بين اين دو متغير در جامعه آمارى موردنظر (شهروندان شهر گر گان) اشاره دارد. سؤال اصلى تحقيق اين بود كه آيا متغير اعتماد اجتماعى بر مشاركت سياسى تأثير خذار است؟ در صورت تأييد، اين تأثير خذارى جِخونه است؟ بر اين اساس نتايج حاصل از تجزيهوتحليل دادهها نشان داد كه بين اعتماد اجتماعى و مشاركت سياسى بِاسخكويان رابطه مثبت و معنادارى وجود دارد. بهطورىكه با افزايش اعتماد اجتماعى، ميزان مشاركت سياسى شهروندان نيز افزايش مى يابد. اين نتايج با يافتههاى

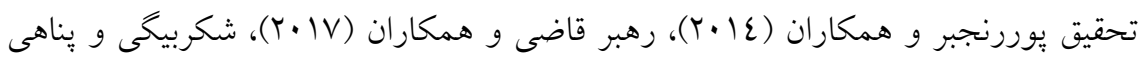

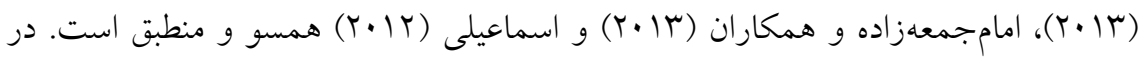
ميان مطالعات خارجى نيز از همسويى و مشابهت نتيجه تحقيق با يافتهاى تحقيقاتى همجون ياتنام، فوكوياما، اينخلهارت، اوسلانر و... مىتوان نام برد. علاوه بر اين، سنجش رابطه اعتماد اجتماعى با ابعاد مشاركت سياسى (رفتار انتخاباتى و مشاركت فعال) نيز موردسنجش قرار 
The relationship between social trust and political participation ...

كرفته است كه در اين مورد، تنها بعد رفتار انتخاباتى با اعتماد اجتماعى رابطه معنادارى به دست آوردهاند.

اعتماد اجتماعى نيز در اين تحقيق شامل ابعاد (اعتماد عمومى، اعتماد نهادى و اعتماد بينشخصى) مىشود كه رابطه آنها با مشاركت سياسى و ابعاد آن مورد آزمون قراركرفته و نتايج بدين شرح است: اعتماد عمومى در سطح مشاركت سياسى و مشاركت فعال و اعتماد بينشخصى در سطح مشاركت سياسى و رفتار انتخاباتى با يكديخر رابطه مثبت و معنادارى

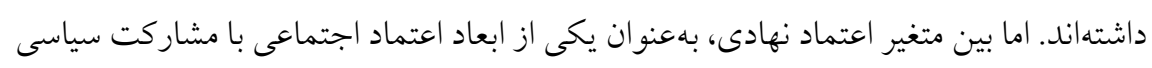
و ابعاد آن رابطه معنادارى مشاهده نشده است. همجنين در جريان سنجش متغيرهاى مستقل و زمينهاى تحقيق نيز شاهد رابطه معنادارى با متغير وابسته تحقيق بودهايم. براين اساس ميزان

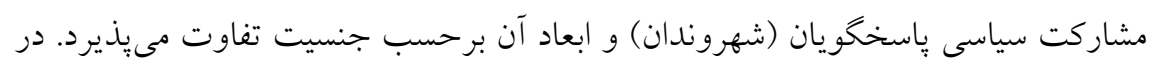
باب رفتار انتخاباتى ياسخكويان برحسب وضعيت تأهل نيز مىتوان اين تفاوت را مشاهده

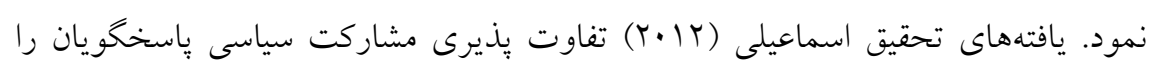
برحسب وضعيت تأهل تأييد مى كند. و در نهايت رابطه ميان متغيرهاى سطح تحصيلات،

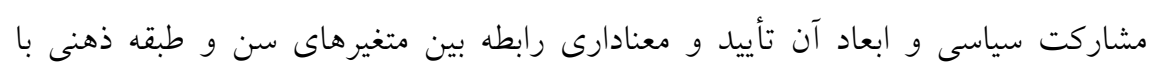
مشاركت سياسى و ابعاد آن، رد شده است. اين نتايج نيز همسو با يافتههاى تحقيق شكربيخى و يناهى (Y| • (Y) درزمينه معنادارى رابطه متغيرهاى وضعيت تأهل، طبقه ذهنى و سن است. اما نكتهاى كه باقى مىماند، اين است كه در تحقيق حاضر بين متغير سن با مشاركت سياسى

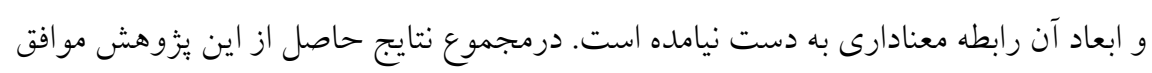
با انتظارات نظرى در حوزه جامعهشناسى سياسى است. بدين معنا كه مطابق نظريههاى جامعه

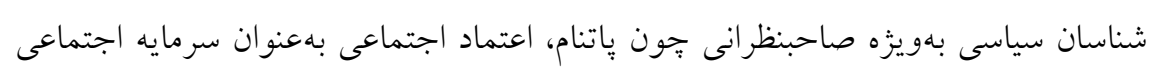
شناختى و بخشى از هنجارهاى جامعه؛ ارتباط وثيقى با مشاركت سياسى دارد. كر بحه نتايج تحقيقات دامنهدار ياتنام مربوط به كشور ايتاليا است، لكن استنتاجهاى نظرى آن قابلتعميم 
Social Welfare Quarterly, Vol 18, Fall 2018, No 70

به جوامع ديخر نيز هست. بدينسان اعتماد اجتماعى بهويزه دو بعد اعتماد در روابط بين

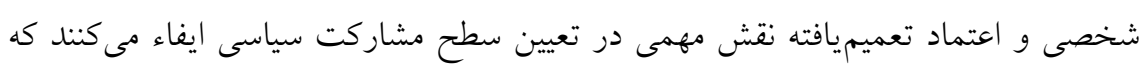

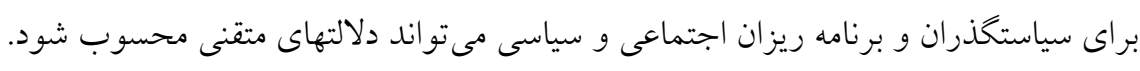

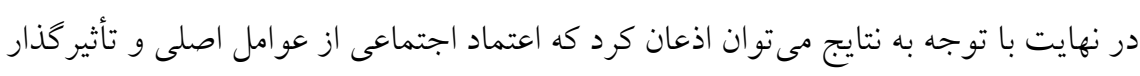

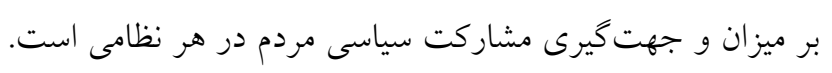


- Fukuyama, F. (1995). Trust: Social Virtues and the Creation of Prosperity. NY: Free Press.

- Giddens, A. (1991). Modernity and Self-Identity: Self and Society in the Late Modern Age.Stanford University Press.

- Herreros, E. (2004). The Problem of Forming Social Capital: Why Trust? New York: Palgrave Macmillan.

- Imam Jumazadeh, S J., Rahbarghazi, M. R., Isaynejad, A. And marandi, z (2013). Investigating the Relationship Between Social Capital and Political Participation among Students of Isfahan University. Political science journal, 28, pp. 37-68. (In Persian)

- Ismaili, AS, R (2012). The Role of Social Factors on Political Participation in Gonbad Kavoos Town. Quarterly Political Studies, 4 (13), 127-144. (In Persian)

- Kasse, M. (1999). Interpersonal Trust, Political Trust and Noninstitutionalized Political Participation in Western Europe. West European Politics, 22(3), 1-21.

- Khoshfar, Gh. R (2005). Investigating the Effect of Social Splits on Political Participation with Emphasis on Ethnic Gap: A Case Study of Golestan Province, Second Quarterly, 1 (4), 115-132. (In Persian)

- Khoshfar, Gh. R (2009). The Impact of Social Capital on Political Participation, Case Study: Golestan Province, Unpublished Phd dissertation, Allameh Tabatabai University, Tehran. (In Persian)

- Krishna, A. \& Shrader, E. (1999). Social capital Assessment Tool, Conference paper for conference on Social Capital and Poverty Reduction, The World Bank. Late Modern Age, Cambridge: Polity Press.

- Lin, N. (2001). Social Capital: A Theory of Social Structure and Action Cambridge University Press.

- Massoudnia, H Et al. (2015). The study of the effect of social trust on different ways of political participation. Social Issues of Iran, 5 (2), 77-94. (In Persian)

- Mohseni, M And Jarallahi, AS (2004). Social participation in Iran. Tehran: Aaron Publications. (In Persian)

- Niazi, m (2003). Explaining Barriers to Social Participation in Kashan City. Unpublished Phd dissertation, Isfahan University, Isfahan. (In Persian) - Panahi, M. H (2008). Sociology of Women's Political Participation. Tehran: Allameh Tabatabaei University Press. (In Persian) 
- Patnam, R (1999). Democracy and Civil Traditions (Italian Experience and Lessons for Transition Countries) (Translated by M. Dolphorus). Tehran: Salam newspaper publishing. (In Persian)

- Putnam, R. D. (1995a). Tuning in, Tuning out: The Strange Disappearance of Social Capital in America. Political Science and Politics, 27(4), 664-683.

- Putnam, R. D. (1995b). Bowling Alone: America's Declining Social Capital. Journal of Democracy, 6, 65-88.

- Rahbarghazi, M. R., Masoudnia, H., Sadeghi Naghdali, Z. And purée, $H$ (2017). The role of virtual social networks in the desire for electoral participation and political orientation (Case study: Students at Isfahan University). Communication Research, 86, 125-146. (In Persian)

- Rezaei, h (2014). Theories of Political Participation with the Election Approach. Election Studies Quarterly, 2 (56), 7-41. (In Persian)

- Rush M. (2005). Society and politics (translation of patience). Second Edition, Tehran: Publication of the Party. (In Persian)

- Rush, M. (1992). Politics and Society, An Introduction to Political Sociology. London: Harvester.

- Scheufele, D. A. (1999). Framing as a Theory of Media Effects. Journal of Communication, 49(1), 103-122.

- Shekarbeigi, AS And Panahi, h (2013). Societal Factors Affecting Women's Political Participation (Case Study: Women in Gonbad-Kavoos City in Golestan Province). Journal of Sociological Studies of Iran, 5 (18), 152-135. (In Persian)

- Wilkins, K. G. (2000). The Role of Media in Public Disengagement from Disengagement from Political Life. Jurnal of Broadcasting \& Electronic Media,44,569-580.

- Wright, J. D. (1976). The Dissent of the Governed. New York: Academic Press. 